\title{
Immunity check should be performed for all patients with septic shock? No
}

\author{
Didier Payen * (1)
}

๑ 2020 Springer-Verlag GmbH Germany, part of Springer Nature

Although there have been improvements in supportive therapy following the implementation of guideline recommendations [1], severe sepsis and septic shock remain the leading cause of death in ICU patients. As part of efforts to further reduce mortality and morbidity in these patients, the translation into clinical practice of the last decade's discoveries on acute systemic inflammation has become essential. However, the complexity of the global picture of acute inflammation, which varies over time for cell-cell crosstalk within the immune system, cell metabolism shifts and coagulation activation, makes these findings very difficult to apply to the clinical context $[2,3]$. Recent discoveries on acquired immunodepression $[4,5]$, the modification of immune cell metabolism after activation of these cells [6], and the implications of epigenetic control of gene activation [7, 8] have modified the paradigm of acute inflammation, particularly in sepsis. If the development of effective biomarkers to direct new therapeutic strategies towards these discoveries is to be achieved $[9,10]$, several issues have to be solved. The tremendous rise in the number of publications on proposed immune system biomarkers derived from blood cells, plasma, urine, and tissue samples has not yet produced validated markers for routine clinical use $[11,12]$. The impressive list of registered clinical trials on biomarker evaluation confirms the great interest in their clinical development [13]. As for other sepsis biomarkers, immune marker validation should follow the steps applied for other markers [14], a task far from being completed.

The first step is to define the purpose(s) of an immune check and, consequently, the immune targets. An immune check might help to differentially diagnose

${ }^{*}$ Correspondence: dpayen1234@orange.fr

Anesthesiology and Critical Care, UFR de Médecine Villemin, Université Paris 7 Paris Cité Sorbonne, Paris, France sepsis from sterile inflammation, to stratify the intensity of acute inflammation, to predict the risk of complications such as secondary infections, to characterize the recovery period, and, in particular, to predict outcome $[13,14]$. This latter point is an essential consideration in order to limit overtreatment and/or to set up potential specific and costly therapies. Patient heterogeneity makes it difficult to characterize the clinical situation on the basis of one or few immune markers. It is more probable that only a panel of immune markers will be able to provide an informative "sepsis signature" for prognostic purposes. Until now, no immune marker has been successfully clinically validated. The ideal marker should have fast kinetics and high sensitivity and specificity; it should also allow fully automatic low-cost measurement to be regularly repeated. It should also relate to the mechanism(s) of immunosuppression [13, 14]. Immune biomarkers can be divided into two broad categories: diagnostic and prognostic. The immune diagnostic marker should help to discriminate sepsis from sterile inflammation. In 2015, data collected in more than 2500 patients treated for sepsis were reported [15]. In post-hoc analysis, infection was found to be absent or only possible in $43 \%$ of the patients. Surprisingly, these patients with no clear infection had a worse prognosis than those found to have infection [15]. The low rate of positive blood cultures in severe sepsis ( 30\%) [13] emphasizes the necessity to have immune biomarkers capable of distinguishing infection-induced inflammation from sterile causes of inflammation. So far, no immune biomarker has proved sufficiently reliable in this sense. Only procalcitonin (PCT) is clinically used to help diagnose infection-related inflammation, but with no consensus on the cut-off value [16]. The inability to decrease procalcitonin by more than $80 \%$ has been shown to be a significant independent predictor of mortality [17]. However, in the latest update of the Surviving Sepsis Campaign, it was seen as a "minor"

\section{实


marker for differentiating between sepsis and sterile inflammation [1]. PCT was also suggested to be of help in making the clinical decision to discontinue antibiotic treatment [18], but again without consistent results. To date, there are no immune or inflammatory biomarkers with proven accuracy in differentially diagnosing sepsis versus sterile inflammation. Immune prognostic markers should help the clinician to predict the outcome of septic patients, notably the risk of complications. At proteomic level, no proteins have gained credence for this purpose despite the large number of reported studies [13]. While most of them showed [19] significant differences between survivors and non-survivors, none has sufficient proof of specificity to be promoted, especially for personalized use. Is the monitoring of immune cell function becoming more efficient than that of immune mediators? While both approaches might be efficient, this question remains open. Similarly, one can ask whether blood is a good tissue for assessing both systemic and organ immune processes. Only a few studies have addressed this important question in patients $[19,20]$. For the spleen [19] and for bone marrow [20] at least, the modifications observed in blood corresponded well to those observed in tissues. These reports suggest that blood is an adequate biopsy material for investigating the immune system, at least for checking cell functions. As for mediators, the conclusion is without consistent results, since many factors may interfere with the measured functions, which hampers the specificity for individual clinical use [21]. Compared to animal or cellular models, measurement of mediators such as cytokines has been poorly validated [13]. Cohort sizes were usually small, sensitivity and specificity were rarely tested, and a prospective cohort was almost never used to validate the training cohort. To conclude, the performance of this approach to characterize patients on an individual basis remains modest.

The second step is to determine the biological level at which an immune check should be routinely performed. Given the non-validation of mediators, investigators have applied the most recently developed new omics techniques (genomics, transcriptomics, proteomics, and metabolomics). These techniques may become applicable to clinical conditions, progressively becoming more automatic with a decreasing cost per measurement [13, 22 ]. For the moment, they are still essentially used for clinical research purposes for learning about new cellular pathways and molecules related to immune checkpoints [22, 23]. Research involving transcriptomic data, particularly in pediatric septic shock patients, has given important results with regard to efforts to determine a prognostic signature [24]. A similar approach was used in adult patients, with less convincing results $[23,25]$. Until rapid assessment technologies are available and these transcriptomic signatures are clinically validated, this approach cannot be applied routinely in human clinical practice. Among the developed technologies and devices, two methods are gaining credence for clinical use: flow cytometry and mass spectrometry. Flow cytometry is unique in its ability to measure, analyze, and study vast numbers of homogenous or heterogeneous immune cell populations using various fluorescencebased stains. Both surface and/or intracellular markers can be targeted to analyze cell phenotypes, changes in DNA content, phosphorylation states, and so on [21]. Since the early days, significant advances have been made in fluorophore and instrument technologies, with the result that it is now possible to quantify up to 18 markers at a time. These advances, however, are challenging the reproducibility and ultimately the ability to generate meaningful results for clinical immune checks [26, 27]. Because of actual manual gating, flow cytometry is still underused, and should, therefore, strive to move rapidly towards greater automation for large numbers of samples and fluorophores [28]. Mass spectrometry (MS), often the method of choice to detect metabolomic and proteomic changes, is increasingly used for evaluating the temporal evolution of sepsis [29]. Various biological samples (blood, plasma, tissue samples, and urine) can be used for MS study of immune biomarkers [30]. To be informative, this "destructive technique" has to have one or more dimensions of protein separation on complex samples (plasma, urine, blood). Among the benefits of the MS method, the integration of both inflammatory protein markers and the consequences on metabolomic molecules in sepsis is a valuable information, which can be compared with healthy volunteers' patterns. Septic patients can then be stratified by severity, timing of sepsis progression, and the presence of causal pathogens. Again, MS clinical studies have been used primarily for research purposes and cannot be recommended for clinical practice [31]. However, there is no doubt that MS will rapidly be applied in large trials to validate immune mediator signatures of sepsis and evaluate their consequences at cell metabolism level.

The third step, or point to clarify, concerns the choice between cell function checking and the use of immune checkpoints. Important studies involving testing of the proteomic method and flow cytometry expression of surface of molecules have been reported [11, 12, 31-35]. Most of these studies looked at timeline-dependent changes in monocyte and/or lymphocyte quantitative expression of surface molecules. The marker with cell surface expression most frequently tested was HLA-DR, a functional marker of the Major Histocompatibility Complex II that is expressed at the cell surface of the presenting antigen cell [36]. Most of the studies demonstrated 
an early, profound, and sustained downregulation of HLA-DR expression in blood monocytes. The ability of HLA-DR expression monitoring to predict mortality is not completely established [35], and its specificity and sensitivity remain to be determined in large clinical trials. However, the validity of persistent low HLA-DR expression as a risk factor for secondary infections has been well documented [11, 12, 32-35]. Thanks to the easily repeatable measurements, this method may help with clinical decision-making and guide the therapies designed to "reprogram" the immunodepressed Antigen Presenting Cells (APC), as recently reported [32-34, 37]. Before it can enter general clinical use, further work is required to better standardize the method and to fix a cut-off value for diagnosing acquired immunodepression. Large cohorts of ICU patients with monitoring of circulating monocyte expression of HLA-DR might help to answer the following important questions: Is HLA-DR downregulation more pronounced in sepsis compared with other life-threatening situations [33]? Is it the depth or duration of HLA-DR downregulation that needs to be considered? At what level of recovered HLA-DR expression should immune stimulation be stopped?

Before requesting an immune check, the clinician should know the pre-sepsis level of immune parameters, especially when chronic diseases are present and treated. It is reasonably possible that patients with diabetes, liver cirrhosis, organ transplantation, cancer, and so on, may have chronic modification of their innate and adaptive immunity. As previously reported, acquired immunodepression has been observed in a different context for ICU admission, which may expose the patients to a similar risk of secondary infections. Future studies should, therefore, focus on these specific clinical traits, to stratify the immune checking [33]. Little is known about immune check values in these contexts and these should, therefore, be determined. For example, surgical-induced stress seems to induce a similar acquired immunodepression [38] to that seen in in non-surgical sepsis.

In conclusion, the basic science data on molecular and cellular immune patterns in sepsis provide new information, suggesting that there may eventually be a place for immune checkpoints in clinical practice to evaluate the severity and prognosis of severe sepsis cases. However, major gaps must be addressed before these data can be transposed to human sepsis [21]. The applicability of the new "omics" tools to clinical conditions requires further development to clarify the role of immune cells, and to investigate the organ-specific immune response and the role of the gut microbiota. Immunological tests need to be better standardized and more automated, especially when an immunotherapy is under discussion. For these reasons, routine immune checks in human sepsis cannot yet be actually recommended.

Compliance with ethical standards

Conflicts of interest

The author has no conflict of interest.

\section{Publisher's Note}

Springer Nature remains neutral with regard to jurisdictional claims in published maps and institutional affiliations.

Received: 31 October 2019 Accepted: 28 December 2019

Published online: 2 March 2020

\section{References}

1. Levy MM, Evans LE, Rhodes A (2018) The surviving sepsis campaign bundle: 2018 update. Intensive Care Med 44:925-928

2. Medzhitov R (2008) Origin and physiological roles of inflammation. Nature 454:428-435

3. van der Poll T, van de Veerdonk FL, Scicluna BP, Netea MG (2017) The immunopathology of sepsis and potential therapeutic targets. Nat Rev Immunol 17:407-420

4. Docke WD, Randow F, Syrbe U, Krausch D, Asadullah K, Reinke P, Volk HD, Kox W (1997) Monocyte deactivation in septic patients: restoration by IFN-gamma treatment. Nat Med 3:678-681

5. Medzhitov R, Schneider DS, Soares MP (2012) Disease tolerance as a defense strategy. Science 335:936-941

6. Dominguez-Andres J, Joosten LA, Netea MG (2019) Induction of innate immune memory: the role of cellular metabolism. Curr Opin Immunol 56:10-16

7. Figueiredo N, Chora A, Raquel H, Pejanovic N, Pereira P, Hartleben B, Neves-Costa A, Moita C, Pedroso D, Pinto A, Marques S, Faridi H, Costa P, Gozzelino R, Zhao JL, Soares MP, Gama-Carvalho M, Martinez J, Zhang Q, Doring G, Grompe M, Simas JP, Huber TB, Baltimore D, Gupta V, Green DR, Ferreira JA, Moita LF (2013) Anthracyclines induce DNA damage response-mediated protection against severe sepsis. Immunity 39:874-884

8. van der Poll T, van de Veerdonk FL, Scicluna BP, Netea MG (2018) Are histones real pathogenic agents in sepsis? Nat Rev Immunol 18:148

9. Netea MG, Balkwill F, Chonchol M, Cominelli F, Donath MY, GiamarellosBourboulis EJ, Golenbock D, Gresnigt MS, Heneka MT, Hoffman HM, Hotchkiss R, Joosten LAB, Kastner DL, Korte M, Latz E, Libby P, MandrupPoulsen T, Mantovani A, Mills KHG, Nowak KL, O’Neill LA, Pickkers P, van der Poll T, Ridker PM, Schalkwijk J, Schwartz DA, Siegmund B, Steer CJ, Tilg $H$, van der Meer JWM, van de Veerdonk FL, Dinarello CA (2017) A guiding map for inflammation. Nat Immunol 18:826-831

10. Odegaard JI, Chawla A (2013) The immune system as a sensor of the metabolic state. Immunity 38:644-654

11. Conway Morris A, Datta D, Shankar-Hari M, Stephen J, Weir CJ, Rennie J, Antonelli J, Bateman A, Warner N, Judge K, Keenan J, Wang A, Burpee T, Brown KA, Lewis SM, Mare T, Roy Al, Hulme G, Dimmick I, Rossi AG, Simpson AJ, Walsh TS (2018) Cell-surface signatures of immune dysfunction risk-stratify critically ill patients: INFECT study. Intensive Care Med 44:627-635

12. Shankar-Hari M, Datta D, Wilson J, Assi V, Stephen J, Weir CJ, Rennie J, Antonelli J, Bateman A, Felton JM, Warner N, Judge K, Keenan J, Wang A, Burpee T, Brown AK, Lewis SM, Mare T, Roy Al, Wright J, Hulme G, Dimmick I, Gray A, Rossi AG, Simpson AJ, Conway Morris A, Walsh TS (2018) Early PREdiction of sepsis using leukocyte surface biomarkers: the ExPRESsepsis cohort study. Intensive Care Med 44:1836-1848

13. van Engelen TSR, Wiersinga WJ, Scicluna BP, van der Poll T (2018) Biomarkers in Sepsis. Crit Care Clin 34:139-152

14. Pierrakos C, Vincent JL (2010) Sepsis biomarkers: a review. Crit Care 14:R15

15. Klein Klouwenberg PM, Cremer OL, van Vught LA, Ong DS, Frencken JF, Schultz MJ, Bonten MJ, van der Poll T (2015) Likelihood of infection in 
patients with presumed sepsis at the time of intensive care unit admission: a cohort study. Crit Care 19:319

16. Wacker C, Prkno A, Brunkhorst FM, Schlattmann P (2013) Procalcitonin as a diagnostic marker for sepsis: a systematic review and meta-analysis. Lancet Infect Dis 13:426-435

17. Schuetz P, Birkhahn R, Sherwin R, Jones AE, Singer A, Kline JA, Runyon MS, SelfWH, Courtney DM, Nowak RM, Gaieski DF, Ebmeyer S, Johannes S, Wiemer JC, Schwabe A, Shapiro NI (2017) Serial procalcitonin predicts mortality in severe sepsis patients: results from the multicenter procalcitonin MOnitoring SEpsis (MOSES) study. Crit Care Med 45:781-789

18. Bouadma L, Luyt CE, Tubach F, Cracco C, Alvarez A, Schwebel C, Schortgen F, Lasocki S, Veber B, Dehoux M, Bernard M, Pasquet B, Regnier B, Brun-Buisson C, Chastre J, Wolff M, Group Pt (2010) Use of procalcitonin to reduce patients' exposure to antibiotics in intensive care units (PRORATA trial): a multicentre randomised controlled trial. Lancet 375:463-474

19. Boomer JS, To K, Chang KC, Takasu O, Osborne DF, Walton AH, Bricker TL, Jarman SD 2nd, Kreisel D, Krupnick AS, Srivastava A, Swanson PE, Green JM, Hotchkiss RS (2011) Immunosuppression in patients who die of sepsis and multiple organ failure. JAMA 306:2594-2605

20. Faivre V, Lukaszewicz AC, Payen D (2016) Downregulation of blood monocyte HLA-DR in ICU patients is also present in bone marrow cells. PLoS One 11:e0164489

21. Rubio I, Osuchowski MF, Shankar-Hari M, Skirecki T, Winkler MS, Lachmann G, La Rosee P, Monneret G, Venet F, Bauer M, Brunkhorst FM, Kox M, Cavaillon JM, Uhle F, Weigand MA, Flohe SB, Wiersinga WJ, Martin-Fernandez M, Almansa R, Martin-Loeches I, Torres A, GiamarellosBourboulis EJ, Girardis M, Cossarizza A, Netea MG, van der Poll T, Scherag A, Meisel C, Schefold JC, Bermejo-Martin JF (2019) Current gaps in sepsis immunology: new opportunities for translational research. Lancet Infect Dis 19:e422-e436

22. Cazalis MA, Lepape A, Venet F, Frager F, Mougin B, Vallin H, Paye M, Pachot A, Monneret $G$ (2014) Early and dynamic changes in gene expression in septic shock patients: a genome-wide approach. Intensive Care Med Exp 2:20

23. Davenport EE, Burnham KL, Radhakrishnan J, Humburg P, Hutton P, Mills TC, Rautanen A, Gordon AC, Garrard C, Hill AV, Hinds CJ, Knight JC (2016) Genomic landscape of the individual host response and outcomes in sepsis: a prospective cohort study. Lancet Respir Med 4:259-271

24. Wong HR, Cvijanovich NZ, Anas N, Allen GL, Thomas NJ, Bigham MT, Weiss SL, Fitzgerald J, Checchia PA, Meyer K, Shanley TP, Quasney M, Hall M, Gedeit R, Freishtat RJ, Nowak J, Shekhar RS, Gertz S, Dawson E, Howard K, Harmon K, Beckman E, Frank E, Lindsell CJ (2015) Developing a clinically feasible personalized medicine approach to pediatric septic shock. Am J Respir Crit Care Med 191:309-315

25. Payen D, Lukaszewicz AC, Belikova I, Faivre V, Gelin C, Russwurm S, Launay JM, Sevenet N (2008) Gene profiling in human blood leucocytes during recovery from septic shock. Intensive Care Med 34:1371-1376
26. Venet F, Guignant C, Monneret G (2011) Flow cytometry developments and perspectives in clinical studies: examples in ICU patients. Methods Mol Biol 761:261-275

27. Gondhalekar C, Rajwa B, Patsekin V, Ragheb K, Sturgis J, Robinson JP (2018) Alternatives to current flow cytometry data analysis for clinical and research studies. Methods 134-135:113-129

28. Zouiouich M, Gossez M, Venet F, Rimmele T, Monneret G (2017) Automated bedside flow cytometer for mHLA-DR expression measurement: a comparison study with reference protocol. Intensive Care Med Exp 5:39

29. Ludwig KR, Hummon AB (2017) Mass spectrometry for the discovery of biomarkers of sepsis. Mol Biosyst 13:648-664

30. Luan H, Wang X, Cai Z (2019) Mass spectrometry-based metabolomics: targeting the crosstalk between gut microbiota and brain in neurodegenerative disorders. Mass Spectrom Rev 38:22-33

31. Seymour CW, Yende S, Scott MJ, Pribis J, Mohney RP, Bell LN, Chen YF, Zuckerbraun BS, Bigbee WL, Yealy DM, Weissfeld L, Kellum JA, Angus DC (2013) Metabolomics in pneumonia and sepsis: an analysis of the GenIMS cohort study. Intensive Care Med 39:1423-1434

32. Hotchkiss R, Olston E, Yende S, Angus D, Moldawer L, Crouser E, Martin G, Coopersmith C, Brakenridge S, Mayr F, Park P, Ye J, Catlett I, Girgis I, Grasela D (2019) Immune checkpoint inhibition in sepsis: a phase $1 \mathrm{~b}$ randomized, placebo-controlled, single ascending dose study of antiprogrammed cell death-ligand 1 antibody (BMS-936559). Crit Care Med 47:632-642

33. Lukaszewicz AC, Grienay M, Resche-Rigon M, Pirracchio R, Faivre V, Boval B, Payen D (2009) Monocytic HLA-DR expression in intensive care patients: interest for prognosis and secondary infection prediction. Crit Care Med 37:2746-2752

34. Francois $B$, Jeannet $R$, Daix T, Walton AH, Shotwell MS, Unsinger J, Monneret G, Rimmele T, Blood T, Morre M, Gregoire A, Mayo GA, Blood J, Durum SK, Sherwood ER, Hotchkiss RS (2018) Interleukin-7 restores lymphocytes in septic shock: the IRIS-7 randomized clinical trial. JCI Insight 2018:3

35. Monneret G, Lepape A, Voirin N, Bohe J, Venet F, Debard AL, Thizy H, Bienvenu J, Gueyffier F, Vanhems P (2006) Persisting low monocyte human leukocyte antigen-DR expression predicts mortality in septic shock. Intensive Care Med 32:1175-1183

36. Venet F, Lukaszewicz AC, Payen D, Hotchkiss R, Monneret G (2013) Monitoring the immune response in sepsis: a rational approach to administration of immunoadjuvant therapies. Curr Opin Immunol 25:477-483

37. Payen D, Faivre V, Miatello J, Leentjens J, Brumpt C, Tissieres P, Dupuis C, Pickkers P, Lukaszewicz AC (2019) Multicentric experience with interferon gamma therapy in sepsis induced immunosuppression A case series. BMC Infect Dis 19:931

38. Kawasaki T, Ogata M, Kawasaki C, Tomihisa T, Okamoto K, Shigematsu A (2001) Surgical stress induces endotoxin hyporesponsiveness and an early decrease of monocyte mCD14 and HLA-DR expression during surgery. Anesth Analg 92:1322-1326 